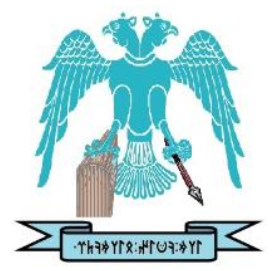

JOURNAL OF ENERGY SYSTEMS

2022, 6(1)

\title{
Lab-scale biogas production from co-digestion of super-intensive shrimp sludge and potential biomass feedstocks
}

\author{
Tran Sy Nam (D) \\ Can Tho University, 3/2 Street, Xuan Khanh Ward, Ninh Kieu District, Can Tho City, 900000, Vietnam, tsnam@ctu.edu.vn \\ *Huynh Van Thao (1) \\ Can Tho University, 3/2 Street, Xuan Khanh Ward, Ninh Kieu District, Can Tho City, 900000, Vietnam, hvthao@ctu.edu.vn \\ Huynh Cong Khanh (D) \\ Can Tho University, 3/2 Street, Xuan Khanh Ward, Ninh Kieu District, Can Tho City, 900000, Vietnam, hckhanh@ctu.edu.vn \\ Nguyen Trong Luan (D) \\ FPT University, Nguyen Van Cu Street, An Binh Ward, Ninh Kieu District, Can Tho city, 90000, Vietnam, luannt73@ fe.edu.vn \\ Nguyen Vo Chau Ngan (D) \\ Can Tho University, 3/2 Street, Xuan Khanh Ward, Ninh Kieu District, Can Tho City, 900000, Vietnam, nvcngan@ctu.edu.vn \\ Huynh Thi Diem (1C) \\ Can Tho University, 3/2 Street, Xuan Khanh Ward, Ninh Kieu District, Can Tho City, 900000, Vietnam, htdiem@ctu.edu.vn \\ Dinh Thai Danh (D) \\ Can Tho University, 3/2 Street, Xuan Khanh Ward, Ninh Kieu District, Can Tho City, 900000, Vietnam, dtdanh@ctu.edu.vn \\ Nguyen Van Cong (D) \\ Can Tho University, 3/2 Street, Xuan Khanh Ward, Ninh Kieu District, Can Tho City, 900000, Vietnam, nvcong@ctu.edu.vn
}

\begin{tabular}{|c|c|c|c|}
\hline * Correspondin & $\begin{array}{r}\text { Submitted: } \\
\text { Accepted: } \\
\text { Published: }\end{array}$ & $\begin{array}{l}24.07 .2021 \\
03.02 .2022 \\
31.03 .2022\end{array}$ & $\underset{\substack{\text { Check for } \\
\text { updates }}}{(\text { D }}$ \\
\hline Abstract: & $\begin{array}{l}\text { This study evaluated biogas production potentials from local biomass feed } \\
\text { rice straw (RS), steamed lemongrass (SL), bagasse (BA) and desiccated coc } \\
\text { intensive shrimp sludge (SS) anaerobic digestion. A series of batch } \\
\text { experiments was conducted at an organic loading rate of } 50 \mathrm{~g}-\mathrm{VS} \mathrm{L}^{-1} \text { and a } \\
\text { mesophilic conditions. The results indicate that co-digested biomass substra } \\
\text { than single sludge except for DC supplementation, which exhibited a seve } \\
\text { methanogenesis activities. A reactor supplemented with BA achieved the } \\
\text { production ( } 126.78 \mathrm{~L} \mathrm{kg-VS}_{\text {added }^{-1}} \text { ), which increased biogas yields } 53.70 \% \\
\text { sludge reactor. Furthermore, reactors with RS and SL increased biogas yi } \\
29.21 \% \text {, respectively. Irrespective of initial materials, the } \mathrm{H}_{2} \mathrm{~S} \text { conc } \\
\text { compositions was measured at very high levels ( } 23,710-65,040 \text { ppm) } \\
\text { digestion, while a decreasing trend was recorded for the remaining digestion } \\
\text { yet still maintained relatively high levels ( } 5,873-9,155 \mathrm{ppm}) \text {. The study sugg } \\
\text { should focus on pH neutralization within the reactor with DC substrates and } \\
\text { composition. }\end{array}$ & $\begin{array}{l}\text { stocks comp } \\
\text { onut (DC) } \\
\text { anaerobic } \\
\text { C/N ratio of } \\
\text { tes are mor } \\
\text { re pH inhil } \\
\text { ighest over: } \\
\text { ompared to } \\
\text { elds by } 26 . \\
\text { entration it } \\
\text { after } 10-15 \\
\text { period }(16- \\
\text { ests that futt } \\
{ }_{2} \mathrm{~S} \text { removal }\end{array}$ & $\begin{array}{l}\text { sing of } \\
\text { super- } \\
\text { gestion } \\
5 \text { under } \\
\text { uitable } \\
\text { ion for } \\
\text { biogas } \\
\text { mono- } \\
\% \text { and } \\
\text { biogas } \\
\text { days of } \\
\text { days), } \\
\text { works } \\
\text { biogas }\end{array}$ \\
\hline
\end{tabular}

Keywords: Batch anaerobic digestion, Biogas production, Biomass feeding, Co-digestion, Shrimp sludge, Super-intensive shrimp cultivation

\begin{tabular}{|c|c|}
\hline $\begin{array}{c}\text { Cite this paper } \\
\text { as: }\end{array}$ & $\begin{array}{r}\text { Nam, T.S., Thao H.V., Khanh, H.C., Luan N.T., Ngan, N.V.C., Diem, H.T., Danh, D.T., \& Cong, N.V., Lab- } \\
\text { scale biogas production from co-digestion of super-intensive shrimp sludge and potential biomass } \\
\text { feedstocks. Journal of Energy Systems 2022; 6(1): 131-142, DOI: 10.30521/jes.973569 }\end{array}$ \\
\hline
\end{tabular}

(c) 2022 Published by peer-reviewed open access scientific journal, JES at DergiPark (https://dergipark.org.tr/en/pub/jes) 


\section{INTRODUCTION}

Super-intensive shrimp aquaculture is increasingly practiced in the coastal provinces of the Vietnamese Mekong Delta region. The production model produces a large amount of shrimp sludge due to highdensity stocking and high daily water exchange. The effectively untreated sludge is discharged directly into waterbodies resulted in environmental contamination. Developing alternative methods for processing this sludge is urgently required, with respect to limiting both cultivation-related risks and environmental degradation. Although anaerobic digestion is recognized as a well-known technology to treat biodegradable wastes [1], it is still a novel technical measure for effective treatment of sludge produced from super-intensive shrimp farms with many challenges remaining to recuperate renewable energy effectively [2,3]. Implementation of the technology in processing super-intensive shrimp sludge has received much attention in recent years due to its applicable characteristics, which offer important benefits for supplying decentralized renewable energy. However, biogas production from the sludge is generally as less efficient [4]. This could be attributed to its low carbon source and high nitrogen content [5], which cause a $\mathrm{C} / \mathrm{N}$ ratio imbalance; simultaneously, the high salinity is also considered as a major concern in anaerobic digestion technologies [6,7]. Salinity is however difficult to tackle due to the hightech and high costs involved, while carbon deficiency is normally supplemented by additional biomass inputs $[8,9]$. Thus, a number of studies have focused on the selection of supplementary materials to combine with shrimp sludge to reach an improved $\mathrm{C} / \mathrm{N}$ ratio of $25-30$, required for optimizing anaerobic digestion $[8,10,11]$.

In the Vietnamese Mekong Delta, agricultural production plays a leading role in local livelihood activities, and contributes up to $50 \%$ of national gross domestic product [12]. As such, agricultural residues are abundant in almost all localities; especially, rice straw which is annually produced at approximately $26 \mathrm{Mt} \mathrm{year}^{-1}$ [13]. In parallel, large quantities of residual biomass such as bagasse from sugar production, steamed lemongrass leaves from essential oil production, and desiccated coconut from candy production are considered unutilized potential sources [14]. Combining locally available biomass and shrimp sludge with a more favorable $\mathrm{C} / \mathrm{N}$ ratio potentially promotes biogas production. Several previous studies have undertaken co-digestion between potential biomass inputs and shrimp sludge for biogas production $[12,14]$. However, these experiments have mostly concentrated on accelerating biogas production conditions by supplementing methanogenesis bacteria and stainless-steel fermenters. However, the optimization of the $\mathrm{C} / \mathrm{N}$ ratio by co-digestion between shrimp sludge and additional biomass feedstocks abundant in the Vietnamese Mekong Delta has not been thoroughly addressed in previous studies. Thus, this study investigates the use of different biomass feedstocks and superintensive shrimp sludge at optimal $\mathrm{C} / \mathrm{N}$ ratio for biogas production under batch mesophilic anaerobic digestion. The study provides significant recommendations for selecting potential biomass to combine with shrimp sludge for biogas production in coastal areas.

\section{MATERIAL AND METHOD}

\subsection{Materials}

Shrimp sludge (SS) was mixed with the four different locally sourced biomass inputs. These were rice straw (RS), steamed lemongrass (SL), bagasse (BA) and desiccated coconut (DC). For the inoculum, the shrimp sludge (SS) was collected from siphoning ponds of a super-intensive white-leg shrimp farm at Tien Giang province $\left(10^{\circ} 14^{\prime} 05.1^{\prime \prime} \mathrm{N}, 106^{\circ} 43^{\prime} 18.6^{\prime \prime} \mathrm{E}\right)$. The sludge was taken following 70 days of shrimp culturing and mainly consisted of daily shrimp excreta and leftover-settled feed. For the additional biomass, (1) RS was obtained from a rice paddy field after harvesting (variety IR50404); (2) SL was collected from a local private company that extracted essential oil from the leaves by steaming 
leaves at the temperature of $121^{\circ} \mathrm{C}$ and pressure of $1.2 \mathrm{Kpa}$ within 3 hours; (3) BA was gathered from drinking retail shops after juicing, whereas (4) DC was collected from a local coconut factory after squeezing coconut milk. Once collected each biomass material was chopped into small pieces of less than $2 \mathrm{~cm}$. The inoculum and biomass feedstocks were independently mixed and consequently stored at $4^{\circ} \mathrm{C}$ before starting the experiment. The C/N ratio of SS, RS, SL, BA, and DC was $16.80,75.14,60.70$, 103.00 and 53.59, respectively. The characteristic of the inoculum and substrates are shown in Table 1.

Table 1. Main characteristics of inoculum and substrates.

\begin{tabular}{llcccccc} 
& Characteristic & Unit & SS & RS & SL & BA & DC \\
\cline { 2 - 7 } & Moisture & $\%$ & 93.2 & 27.4 & 31.2 & 16.9 & 42.8 \\
& Total solid & $\%$ & 6.80 & 72.6 & 68.8 & 83.1 & 57.2 \\
& Volitive solid & $\% \mathrm{TS}$ & 70.7 & 92.1 & 90.3 & 93.4 & 97.7 \\
& $\mathrm{pH}$ & - & 6.62 & $\mathrm{ND}$ & $\mathrm{ND}$ & $\mathrm{ND}$ & $\mathrm{ND}$ \\
& Salinity & $\mathrm{mg} \mathrm{L}^{-1}$ & 10.2 & $\mathrm{ND}$ & $\mathrm{ND}$ & $\mathrm{ND}$ & $\mathrm{ND}$ \\
& $\mathrm{NH}_{4}^{+}$ & $\mathrm{mg} \mathrm{L}^{-1}$ & 220 & $\mathrm{ND}$ & $\mathrm{ND}$ & $\mathrm{ND}$ & $\mathrm{ND}$ \\
& $\mathrm{SO}_{4}{ }^{2-}$ & $\mathrm{mg} \mathrm{L}^{-1}$ & 983 & $\mathrm{ND}$ & $\mathrm{ND}$ & $\mathrm{ND}$ & $\mathrm{ND}$ \\
& $\mathrm{TC}$ & $\% \mathrm{TS}$ & 63.0 & 58.6 & 52.2 & 53.9 & 56.2 \\
& $\mathrm{TN}$ & $\%$ & 3.75 & 0.78 & 0.86 & 0.52 & 1.05 \\
Note: $N D$ (not detected) & $\mathrm{C} / \mathrm{N}$ & - & 16.8 & 75.14 & 60.70 & 103.00 & 53.59 \\
\cline { 2 - 7 } & & & & & & &
\end{tabular}

\subsection{Experimental Design}

The reactor used in this study was a 5-L glass bottle. However, the real working volume was set up to 4-L. The digester included a gas collection and outlet sampling systems certainly set onto the plastic lid. The system was fabricated by an inner 6-mm diameter plastic pipe connected directly from the air headspace's bottle to a 5-L aluminum foil bag, while the outlet sampling system was directly inserted into the inoculum, which was $1 / 2$ the bottle height. The bottle was then tightly closed using a seal tape and a rubber ring placed under the lid. This model was scaled down similarly to the reactor reported by Nam et al. [15]. Before processing, bottles were tested for airtight conditions. Air was pumped into each bottle to a $15-\mathrm{cmH}_{2} \mathrm{O}$ pressure and kept continuously for 2 hours. These airtight-ensured bottles were then used for the experiment. Nitrogen gas was purged in each reactor's headspace for 5 minutes before commencing the experiment to secure the homogeneously initial anaerobic condition. Thereafter, the digester was randomly arranged on a shelf inside a screen-house (Can Tho University, 10 $0^{\circ} 139.02^{\prime \prime} \mathrm{N}$, $105^{\circ} 45^{\prime} 53.64 " \mathrm{E}$ ) under mesophile conditions. The ambient temperature recorded during the experiment varied from $24.7-31.2^{\circ} \mathrm{C}$. A control reactor A (SS) and four co-digestion treatments were investigated in this experiment, including B (SS+RS), C (SS+SL), D (SS+BA), and E (SS+DC). Each treatment was performed in quintuplicate at the same time. The initial organic loading rate for each reactor was set based on the volatile solid (VS) weight at $50 \mathrm{~g}-\mathrm{VS} \mathrm{L}^{-1}$, and a C/N ratio by 25 was calculated by adjusting the SS and biomass substrates based on Equation 1. The reactors were adjusted with de-chlorinated tap water to reach the same test volume $(4 \mathrm{~L})$. Each digester was manually mixed once to ensure materials sank in the inoculum. The fermentation stage was set to 45 days. A mixture including inoculum, feedstocks, and tap water was supplemented based on the designed experimental conditions (Table 2).

Table 2. Lab-scale experimental design.

\begin{tabular}{|c|c|c|c|c|c|c|}
\hline \multirow{2}{*}{ Parameters } & \multirow{2}{*}{ Unit } & \multicolumn{5}{|c|}{ Reactors } \\
\hline & & A & $\mathrm{B}$ & $\mathrm{C}$ & $\mathrm{D}$ & $E$ \\
\hline SS & $\mathrm{g}$ & 190.4 & 112.0 & 99.9 & 114.2 & 98.9 \\
\hline $\mathrm{RS}$ & $\mathrm{g}$ & NA & 88.0 & NA & NA & NA \\
\hline SL & $\mathrm{g}$ & NA & NA & 100.1 & NA & NA \\
\hline BA & $\mathrm{g}$ & NA & NA & NA & 85.8 & NA \\
\hline $\mathrm{DC}$ & $\mathrm{g}$ & NA & NA & NA & NA & 101.1 \\
\hline $\mathrm{C} / \mathrm{N}$ co-substrate & - & $16.8^{\dagger}$ & 25 & 25 & 25 & 25 \\
\hline Total VS added & $\mathrm{g}$ & 190.4 & 200 & 200 & 200 & 200 \\
\hline Total volume & $\mathrm{mL}$ & 4000 & 4000 & 4000 & 4000 & 4000 \\
\hline
\end{tabular}




\subsection{Analytical Methods}

The total solids (TS), volatile solids (VS), total carbon (TC), total nitrogen (TN), $\mathrm{NH}_{4}{ }^{+}$, and $\mathrm{SO}_{4}{ }^{2-}$ were all determined according to the Standard Methods [16]. The $\mathrm{pH}$ and the redox potential of digester liquids were measured directly in the reactors through the sampling outlet using a pH meter (TOA DKK, Japan) and a redox meter (TOA DKK, Japan). The daily biogas was collected in aluminum foil bags and was measured by a gas volume meter (TG 02 , Ritter, Germany). The $\mathrm{CO}_{2}$ and $\mathrm{H}_{2} \mathrm{~S}$ were measured daily using a Biogas 5000 gas analyzer (Geotechnology, UK). Methane concentration (v/v) was determined by a Shimadzu GC 2014AT (Shimadzu, Japan) gas chromatograph with a thermal conductivity detector (TCD) and a 60/80 Carboxen-1000 column (L x O.D x I.D: $4.57 \mathrm{~m}$ x $3.1 \mathrm{~mm} \times 2.1 \mathrm{~mm}$ ). The operational temperatures of the injection port, column oven, and detector were $240^{\circ} \mathrm{C}, 180^{\circ} \mathrm{C}$, and $240^{\circ} \mathrm{C}$, respectively. Nitrogen was used as the carrier gas at a flow rate of $10 \mathrm{~mL} \mathrm{~min}^{-1}$. A standard gas mixture (Air Liquids Ltd., Singapore) composed of $49.95 \%$ methane, $30.05 \%$ carbon dioxide in nitrogen was used for calibration. A $2.5 \mathrm{~mL}$ gas-tight Samplelock ${ }^{\circledR}$ syringe (Hamilton, USA) was used for gas sampling.

\subsection{C/N Ratio Calculation in Co-Substrate Feedstocks}

The $\mathrm{C} / \mathrm{N}$ ratio was determined by dividing the total organic carbon content by the total nitrogen content, according to the following equation [8].

$$
\frac{C}{N}=\frac{W_{1} C_{2}+W_{2} C_{2}}{W_{1} C_{1}+W_{2} C_{2}}
$$

Where $\mathrm{W}_{1}$ and $\mathrm{W}_{2}$ were the VS weight in a single substrate in the mixture, $\mathrm{C}_{1}$ and $\mathrm{C}_{2}$ were the organic

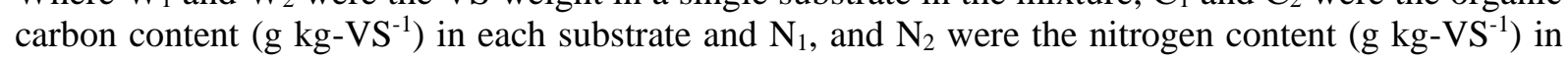
each substrate.

\subsection{Data Processing}

All the data were tested for variance homogeneity prior to statistical analysis. One-way ANOVA and Duncan post-hoc tests were conducted for multiple biogas yield comparisons among treatments. An alpha $(\alpha)$ level of 0.05 was used to determine the statistical significance of all analyses. The analysis was performed using the statistical software IBM SPSS (version 22.0 for Windows). The results were presented in tabular form and graphs were plotted using SigmaPlot software version 14.0.

\section{RESULTS}

\subsection{Biogas Production}

Fig. 1. shows daily biogas production recorded for the five different biomass feedstock treatments (A, $\mathrm{B}, \mathrm{C}, \mathrm{D}$ and $\mathrm{E})$. The biogas production of all reactors rapidly increased in the first 7 days and reached

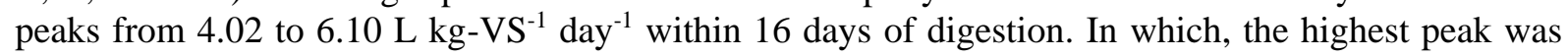
found in reactor B (RS + SS), while reactor A (only SS) showed the lowest production peak. Thereafter, although volume of daily biogas production varied among reactors, a stable level of o bio-gasification remained until the end of the experiment. As can be seen from Fig. 1, almost all reactors displayed a similar trend in the acceleration of biogas production with the exception of reactor E. On the other hand, co-digestion of DC and SS in reactor E obviously limited biogas production from day 14 onwards. Here, the limited volume of daily biogas production was not measurable. While the mean values of daily biogas production in reactors $\mathrm{A}, \mathrm{B}, \mathrm{C}$, and $\mathrm{D}$ reached a stable output period (from 16 to 45 days) measured at 2.29, 2.43, 2.78, and 3.51 ${\mathrm{L} \mathrm{kg}-\mathrm{VS}_{\text {added }}}^{-1}$ day $^{-1}$. Co-digestion of BA and SS in reactor D was 
higher than that of reactors A, B, and C. This difference was estimated at $53.1 \%, 44.1 \%$ and $25.8 \%$, respectively.

It can be observed that the co-digestion treatments accelerated biogas production at the beginning of the experiment when compared to solely the shrimp sludge substrate (treatment A). Specifically, codigestion treatments including $\mathrm{B}, \mathrm{C}$, and $\mathrm{D}$ produced biogas from day 7 - 9 onwards, with initial volumes varying between 2.99 - $3.84 \mathrm{~L} \mathrm{kg-VS}^{-1}$ day $^{-1}$, while the biogas production from the shrimp sludge (A) was only $0.92 \mathrm{~L} \mathrm{~kg}-V S^{-1}$ day $^{-1}$. At the end of the experiment, reactors were still producing biogas, but the volume was lower than that of previous stages. Among the four co-digestion treatments, the mixture of SS and BA (treatment D) achieved the highest biogas production values, suggesting the potential of bagasse biomass for biogas production.

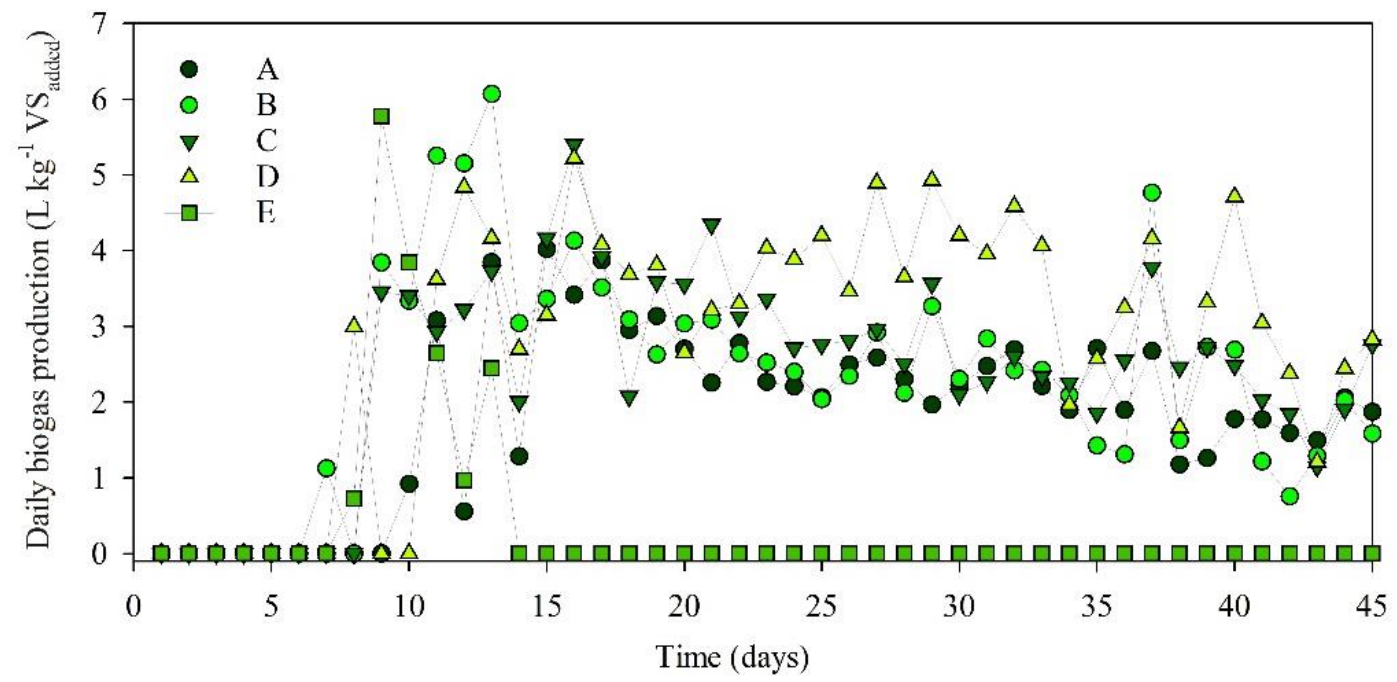

Figure 1. Daily biogas production in reactors $A, B, C D$, and $E$.

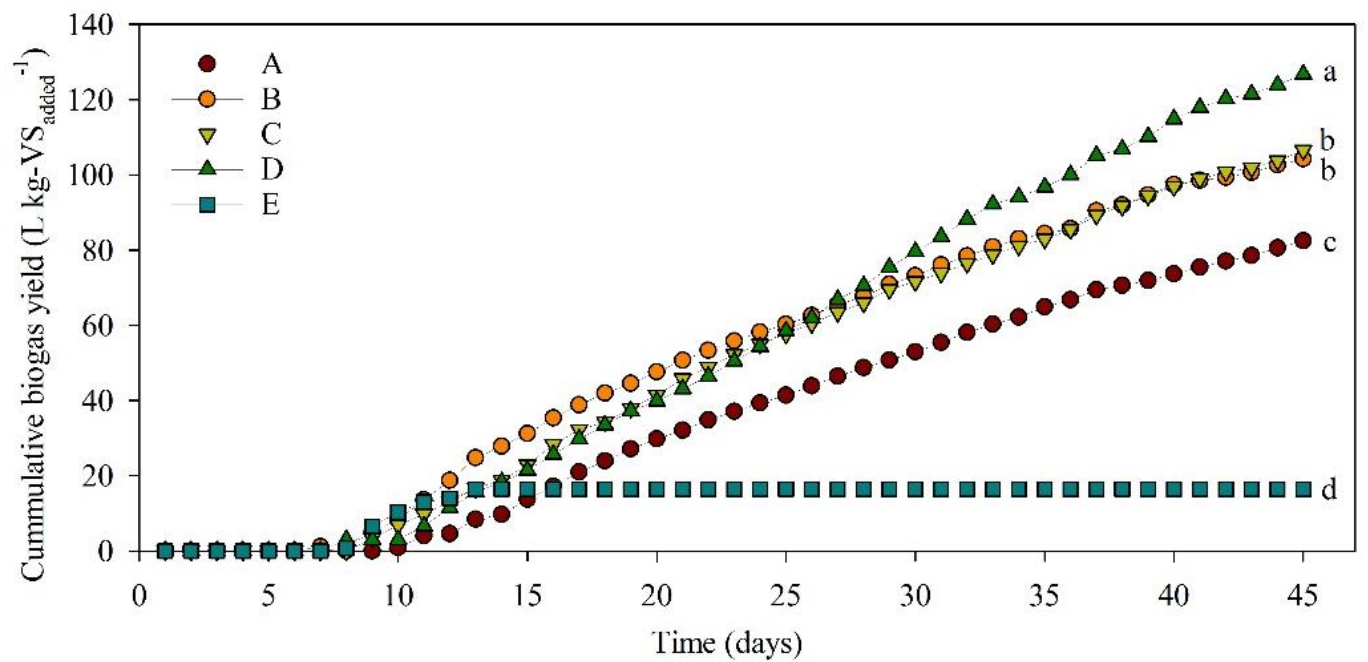

Figure 2. Cumulative biogas yield in reactors $A, B, C D$, and $E$.

The cumulative biogas production for the treatments A, B, C, D, and E are shown in Fig. 2. Out of all co-digestion reactors, treatment $\mathrm{D}$ showed the highest biogas yield over the whole digestion period $(p<0.05)$. This is followed by treatments $B$ and $C$, which share a similar tendency $(p>0.05)$, while treatment $\mathrm{E}$ yielded the worst cumulative biogas production. It was found that the biogas yield of the co-digestion reactors $\mathrm{B}, \mathrm{C}$, and $\mathrm{D}$ was $26.40 \%, 29.21 \%$, and $53.70 \%$ higher than that of reactor A (reactor control; biogas yield was $82.48{\mathrm{~L} \mathrm{~kg}-\mathrm{VS}_{\text {added }}}^{-1}$ ), respectively. By comparison, the methane yield 
for the co-digestion reactors $\mathrm{B}, \mathrm{C}$, and D was $81.40 \%, 85.06 \%$, and $107.7 \%$ higher than that of reactor A (control reactor; biogas yield was $25.5 \mathrm{~L} \mathrm{~kg}-\mathrm{VS}_{\text {added }}{ }^{-1}$ ). Moreover, Table 3 depicts that the initial $\mathrm{pH}$ and redox potential were appropriate for biogas production and the co-digestion substrates increased $\mathrm{CH}_{4}$ and $\mathrm{CO}_{2}$ concentration in the biogas composition compared with mono-digestion (reactor $\mathrm{A}$ ), yet did not decrease $\mathrm{H}_{2} \mathrm{~S}$.

Table 3. Experimental results from the different reactors $A, B, C D$, and $E$.

\begin{tabular}{|c|c|c|c|c|c|c|}
\hline \multirow{2}{*}{ Parameters } & \multirow{2}{*}{ Unit } & \multicolumn{5}{|c|}{ Reactors } \\
\hline & & $\mathrm{A}$ & $\mathrm{B}$ & $\mathrm{C}$ & $\mathrm{D}$ & $E$ \\
\hline Initial $\mathrm{pH}$ & - & 6.84 & 6.73 & 6.69 & 6.69 & 6.65 \\
\hline Initial redox & $\mathrm{mV}$ & -229 & -280 & -296 & -278 & -221 \\
\hline Retention time & day & 45 & 45 & 45 & 45 & 45 \\
\hline Biogas yield & $\mathrm{L} \mathrm{kg}-\mathrm{VS}_{\text {added }^{-1}}$ & 82.48 & 104.3 & 106.6 & 126.8 & 16.40 \\
\hline $\mathrm{CH}_{4}$ yield & $\mathrm{L} \mathrm{kg} \mathrm{VS}_{\text {added }^{-1}}$ & 25.50 & 46.25 & 47.18 & 52.96 & 2.12 \\
\hline Average $\mathrm{CH}_{4}$ & $\%$ & 30.91 & 44.36 & 44.27 & 41.77 & 12.92 \\
\hline Average $\mathrm{CO}_{2}$ & $\%$ & 29.83 & 31.58 & 33.47 & 37.61 & 43.07 \\
\hline Average $\mathrm{H}_{2} \mathrm{~S}$ & ppm & 7,811 & 7,026 & 6,499 & 10,203 & 7,787 \\
\hline
\end{tabular}

\subsection{Biogas Composition}

Fig. 3 illustrates the methane concentration (v/v) in the biogas composition of reactors A, B, C, D, and E. During the first 7 days, there was insufficient biogas for detecting the composition. At this time in reactors $\mathrm{B}, \mathrm{C}$ and $\mathrm{E}$, the methane content was only about $6.3-7.0 \%$, while reactor $\mathrm{D}$ showed the highest concentration with $18.3 \%$. The mono-digester A with only the shrimp sludge displayed the lowest methane concentration at $4.5 \%$. For reactors $\mathrm{B}, \mathrm{C}$ and $\mathrm{D}$, the methane concentrations increased drastically and obtained $45 \%$ on day 18 and then remained at a stable level until the experimental period concluded. Whereas, treatment A (shrimp sludge) showed a methane concentration of $40 \%$ after 20 days. The biogas production inhibition of treatment $\mathrm{E}$ led to the lowest methane concentration $(<25 \%)$. The maximum biogas content was obtained from reactor $\mathrm{D}$ which contained a mixture between shrimp sludge and bagasse, while suppression was found in the desiccated coconut material.

Fig. 3 shows that the $\mathrm{CO}_{2}$ concentration was highest within the first 15 days of biogas generation. The $\mathrm{CO}_{2}$ content in biogas reached the highest concentration in reactor $\mathrm{A}$ accounting for $60 \%$, while the cosubstrate reactors $\mathrm{B}, \mathrm{C}, \mathrm{D}$, and $\mathrm{E}$ showed $\mathrm{CO}_{2}$ concentrations of $57.1 \%, 45.1 \%, 31.7 \%$ and $36.6 \%$, respectively. Thereafter, $\mathrm{CO}_{2}$ concentrations reduced and reached a stable level (30.4 - 39.2\%). Furthermore, it is apparent that the $\mathrm{H}_{2} \mathrm{~S}$ concentration was seen at a very high in biogas composition. However, the highest concentration was observed in the first week of biogas production (maximum recorded values ranged from $23,710-65,040 \mathrm{ppm}$ ). Thereafter, $\mathrm{H}_{2} \mathrm{~S}$ concentrations rapidly decreased and remained lower $(5,873-9,155 \mathrm{ppm})$. 

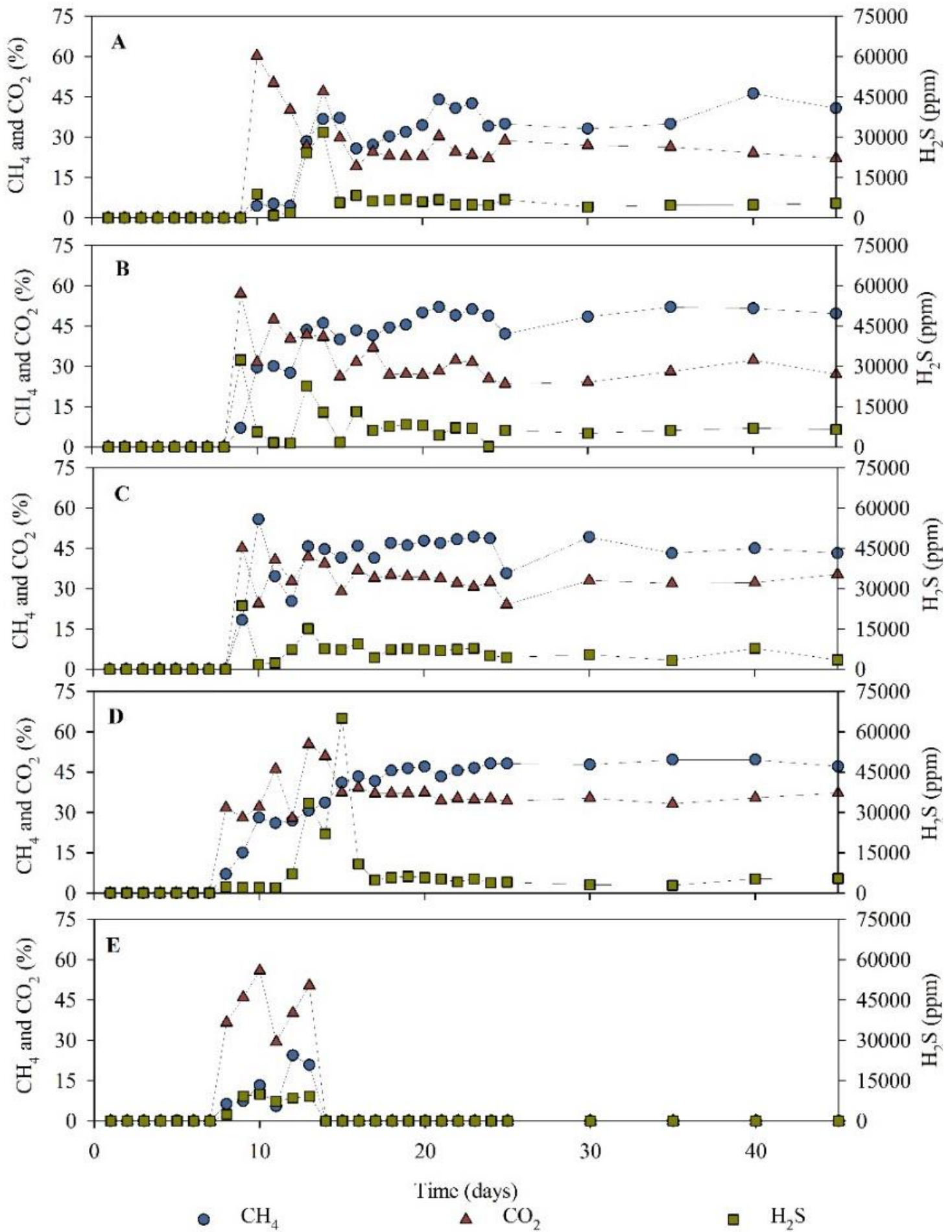

Figure 3. Biogas compositions in reactors.

\section{3. pH and Redox}

During the digestion process, $\mathrm{pH}$ values showed a decreasing tendency in the first 10 days (Fig. 4(a)). The $\mathrm{pH}$ value in co-digestion reactors $(\mathrm{B}, \mathrm{C}, \mathrm{D}$, and $\mathrm{E})$ quickly dropped compared to the $\mathrm{pH}$ in the shrimp sludge reactor (A). Specifically, the $\mathrm{pH}$ values of the treatment of $\mathrm{D}$ and $\mathrm{E}$ significantly decreased on day 1 of the experiment to 5.5, while the other reactors (A, B, and C) sustained a higher pH value of 6.0. However, over time reactor $\mathrm{D}$ gradually recovered a stable $\mathrm{pH}$ condition suitable for biogas production. However, reactor $\mathrm{E}$ showed little improvement and maintained $\mathrm{pH}$ values between 5.10 and 5.27 in the hydrolysis and acidogenesis phases. Notably, the $\mathrm{pH}$ of co-digestion reactors illustrates a 
reverse relationship with daily biogas production if treatment $\mathrm{E}$ is excluded. In particular, the average $\mathrm{pH}$ value of the treatments $\mathrm{A}, \mathrm{B}, \mathrm{C}$, and $\mathrm{D}$ for the whole anaerobic digestion process were $6.67,6.57$, 6.47, and 6.21, respectively; whereas the daily biogas production were $2.29,2.75,2.86$, and $3.43 \mathrm{~L} \mathrm{~kg}$ $\mathrm{VS}_{\text {added }}{ }^{-1}$ day $^{-1}$, respectively.
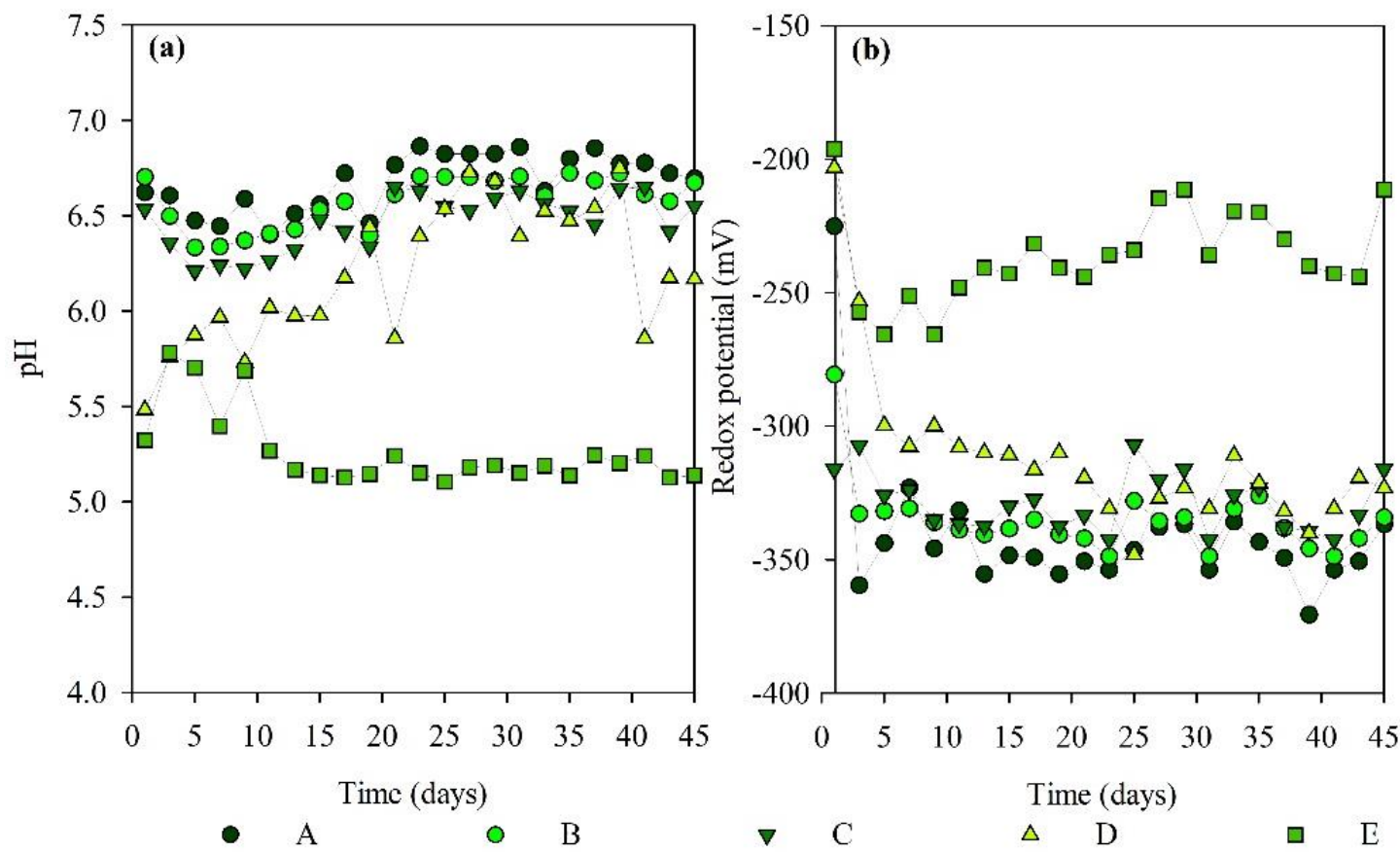

Figure 4. $p H$ value (a) and redox potential (b) in reactors.

Fig. 4(b) shows that the redox potential (Eh) rapidly decreased in the first five days of the experiment and remained stable for the entire fermentation period. In particular, the Eh value varied between -316 and $-196 \mathrm{mV}$ on the first day, in which the reactors $\mathrm{B}$ and $\mathrm{C}$ recorded their lowest values, while treatment $\mathrm{B}$ and $\mathrm{D}$ persisted at higher values as compared to reactor A. Thereafter, the Eh varied between -300 $\mathrm{mV}$ and $-350 \mathrm{mV}$, which indicates that this period transformed to a stable phase and the metabolic status for an anaerobic digestion system was obtained. However, reactor E showed higher fluctuations in Eh values which suggests the ineffectiveness of biogas production. Interestingly the interaction between $\mathrm{pH}$ and Redox potential showed an inverse correlation. Noticeably, the reactors A, B, C, and D with high $\mathrm{pH}$ values showed Eh potentials of $-341 \mathrm{mV},-334 \mathrm{mV},-328 \mathrm{mV}$, and $-310 \mathrm{mV}$, respectively.

\section{DISCUSSION}

In this study, we used locally available biomass as a supplementation feedstock for producing biogas. Bio-gasification was seen to start after 7 - 9 days of digestion for co-digestion reactors of biomass and shrimp sludge, whereas in solely shrimp sludge, bio-gasification was firstly recorded on the $9^{\text {th }}$ day. This indicates that hydrolysis and acidogenic microorganism activities were ongoing in the earlier period and also that co-digestion accelerated the onset of biogas production. Among potential biomass sources, our results showed that co-digestion of DC+SS produces biogas ineffectively, even though $\mathrm{C} / \mathrm{N}$ was adjusted to an optimal value by 25 for the consumption of anaerobic microbial population as suggested by $[10,17]$. This is because a sharp $\mathrm{pH}$ reduction also led to a dramatical accumulation of volatile fatty acids (VFAs), inhibition of methanogenesis bacteria and biogas production suppression [11,18]. For instance, the $\mathrm{pH}$ optimum for methanogenesis is roughly 7.0, while the hydrolysis and acidogenesis periods require $\mathrm{pH}$ values from 5.5 - 6.5 [1]. Previous studies have suggested that $\mathrm{pH}$ should be maintained between 6.8 and 7.2 for single-stage anaerobic systems to avoid the accumulation of VFA concentration $[19,20,21,22]$. Previous studies were revealed a pH reduction in the early stage of co-digestion reactors 
and then gradually recovered $[15,23,24]$, which was a similar trend in our findings. However, several co-digestion reactors displayed a failed $\mathrm{pH}$ recovery after hydrolysis and acidogenesis stages, although the co-digestion maintained an optical $\mathrm{C} / \mathrm{N}$ ratio for the reactor $[25,26]$. Two possible solutions to overcome this problem could be (i) applying two-stage anaerobic digestion to effectively use the different microbiomes in each stage [27], and (ii) measuring $\mathrm{pH}$ in the liquid phase and resultantly adjusting $\mathrm{pH}$ to a favorable range for bio-gasification [28,29]. However, it is not feasible to adjust $\mathrm{pH}$ in reactors with co-substrates derived from biomass due to the high-cost and hi-tech requirements. In addition, the use of oxidation-reduction potential is potentially a great indicator for controlling anaerobic digesters because it reflects the oxidoreduction state. Therefore, redox potential values should be maintained between -100 and $-350 \mathrm{mV}$, which are satisfactory conditions for anaerobic digestion [30].

Data obtained from this study showed that the biogas and methane yield of co-digestion between bagasse and shrimp sludge were approximately $20 \%$ higher than that of co-digestion of rice straw and shrimp sludge, as well as steamed lemongrass and shrimp sludge which indicates its potential use for biogas digestion. Rice straw and steamed lemongrass materials are also two feasible sources of biomass feedstocks that produced $26-29 \%$ higher biogas yields than single shrimp sludge digestion. On the other hand, this study confirms that co-digestion of biomass and shrimp sludge at a C/N ratio of 25/1 significantly increases the effectiveness of biogas production compared to mono-digestion of solely shrimp sludge which is consistent with co-digestion of biomass materials and various waste sources from the previous works $[31,32,33,34]$. In one aspect, the results of this study show that although cosubstrates were adjusted to an appropriated $\mathrm{C} / \mathrm{N}$ ratio, biogas production from the mixture was tentatively lower than that of previous studies $[12,14]$. This could be explained by the effects of salinity in the initial sludge (10.16 mg L $\left.\mathrm{L}^{-1}\right)$ and a shorter retention time within 45 days. It has been reported that the microbial communities of the anaerobic digestion process are stressed by high salinity [7], inhibiting methane production and the degradation of organic compounds [35]. It has been demonstrated that the supplementation of $0.5-2.0 \mathrm{~g}-\mathrm{NaCl} \mathrm{L}{ }^{-1}$ offers beneficial conditions for methane formation, yet methane yield reduces from $36 \%$ to $41 \%$ when $\mathrm{NaCl}$ was added in concentrations of $5-10 \mathrm{~g} \mathrm{~L}^{-1}$ [36]. Moreover, the extension of the fermentation period obviously increases biogas generation due to the degradation of recalcitrant polymers/lignocellulose within the biomass. At the end of the experiment, biogas production still continued indicates that the prolongation of retention time instead of 45 days would significantly increase the yield. It can be seen that biogas yield reached in this study was less than $115 \mathrm{~L} \mathrm{~kg}-\mathrm{VS}_{\text {added }}{ }^{-1}$ (45-day digestion), while biogas yields in a 120-day long experiment with a mixture

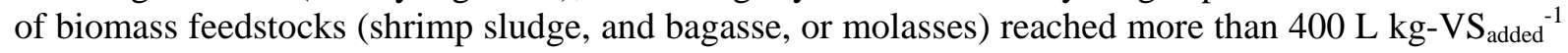
[12]. The findings show that the co-digestion of shrimp sludge and local biomass substrates increased the biogas yield compared with feeding only shrimp sludge. Notably, this study shows that the treatment mixture of shrimp sludge and bagasse obtained highest biogas production. This is consistent with results obtained by [14].

In this study, co-digestion reactors produced $\mathrm{CH}_{4}$ from day seven and obtained a stable level after 18 days of digestion, greater than $45 \%$ (reactors B, C, D), while reactor A obtained $40 \% \mathrm{CH}_{4}$ after 20 days. $\mathrm{CH}_{4}$ generated from reactor $\mathrm{E}$ was insignificant. The finding drew up a low $\mathrm{CH}_{4}$ formation pace and low $\mathrm{CH}_{4}$ concentration compared with the previous study $[12,14]$, although it could be acceptable for biogasto-energy. This could be partly explained by the inhibitory factor of the above-discussed salinity which obtains lower the popular range of methane content in biogas $(50-75 \%)[37,38] . \mathrm{CO}_{2}$ concentration was similar to the $\mathrm{CH}_{4}$ generation trend in the stable stage. However, higher concentration was found in hydrolysis and acidogenesis [38,39], but it was then generally ranged from $24-45 \%$ [40]. $\mathrm{H}_{2} \mathrm{~S}$ content reached very high levels. In the start-up phase (within the first 15 days), the $\mathrm{H}_{2} \mathrm{~S}$ concentration varied between $2.37-6.50 \%$ over the reactors. Although the $\mathrm{H}_{2} \mathrm{~S}$ concentration reduced $0.58-0.92 \%$ in the stable biogas-production phase, it was still high compared to that of common $\mathrm{H}_{2} \mathrm{~S}$ content level in biogas compositions $(0.1-0.3 \%)[37,38,40]$. The high $\mathrm{H}_{2} \mathrm{~S}$ concentration indicates that obtained biogas would be hard to effectively use for many purposes (cooking, heating, or running electrical machinery). $\mathrm{H}_{2} \mathrm{~S}$ is generally known as the most dangerous, toxic and corrosive contaminant in biogas compositions. It is normally recommended to remove it for improving energy efficiency [41]. The high $\mathrm{H}_{2} \mathrm{~S}$ is undesirable in energy consumption, even at low concentrations. $\mathrm{H}_{2} \mathrm{~S}$ concentrations of $150-500 \mathrm{ppm}$ are required 
for internal combustion engines [42], [43]. Thus, $\mathrm{H}_{2} \mathrm{~S}$ removal in biogas is necessary to use biogas devices without corrosion and unpleasant smells effectively.

\section{CONCLUSION}

The results obtained in this study suggested that the co-digestion of super-intensive shrimp sludge and biomass feedstock is a promising approach for biogas production. The biogas yields increased by $26.40 \%, 29.21 \%$, and $53.70 \%$ compared to that from solely shrimp sludge with the co-digestion of SS+RS, SS+SL, and SS+BA, respectively. The co-digestion of SS+DC failed to create a suitable environment for biogas production due to rapid $\mathrm{pH}$ reduction. Irrespective of the input materials, the concentration of $\mathrm{H}_{2} \mathrm{~S}$ in biogas compositions is identical at high levels. Thus, the continuation of the work should focus on (i) circumventing $\mathrm{pH}$ inhibition for improving the stability of the digester systems when DC is added as a co-substrate and (ii) eliminating $\mathrm{H}_{2} \mathrm{~S}$ out of biogas before use.

\section{Acknowledgment}

The authors are very thankful to YUKO-KEISO CO., LTD, JAPAN for funding this research. We also thank Dr. Nigel K. Downes (Researcher - CMI Integrated Expert at Can Tho University) for proofreading the manuscript.

\section{REFERENCES}

[1] Ye, J, Li, D, Sun, Y, Wang, G, Yuan, Z, Zhen, F, Wang, Y. Improved biogas production from rice straw by co-digestion with kitchen waste and pig manure. Waste Management 2013; 33: 2653-2658 DOI: 10.1016/j.wasman.2013.05.014.

[2] Li, J, Wei, L, Duan, Q, Hu, G, Zhang, G. Semi-continuous anaerobic co-digestion of dairy manure with three crop residues for biogas production, Bioresource Technology 2014; 156: 307-313. DOI: 10.1016/j.biortech.2014.01.064.

[3] Luo, G, Ma, N, Li, P, Tan, H, Liu, W. Enhancement of Anaerobic Digestion to Treat Saline Sludge from Recirculating Aquaculture Systems. The Scientific World Journal 2015; 2015:1-5. DOI: $10.1155 / 2015 / 479101$.

[4] Srisertpol, J, Srinakorn, P, Kheawnak, A, and Chamniprasart, K. Estimation of Biogas Production from Shrimp Pond Sediment Using the Artificial Intelligence. Applied Mechanics and Materials 2012; 260-261: 695-700. DOI: 10.4028/www.scientific.net/AMM.260-261.695.

[5] Srivichai, P, Chavalparit, O. Co-digestion of modified tapioca starch sludge and shrimp pond sediment as a method to improve system stability and biogas production. ScienceAsia 2020; 46:1-9. DOI: 10.2306/scienceasia1513-1874.2020.017.

[6] Chen, Y, Cheng, JJ, Creamer, KS. Inhibition of anaerobic digestion process: A review. Bioresource Technology 2007; 99:4044-4064. DOI: 10.1016/j.biortech.2007.01.057.

[7] Zhang, J, Zhang, R, He, Q, Ji, B, H, Wang, Yang, K. Adaptation to salinity: Response of biogas production and microbial communities in anaerobic digestion of kitchen waste to salinity stress. Journal of Bioscience and Bioengineering 2020. 130:173-178. DOI: 10.1016/j.jbiosc.2019.11.011.

[8] Wang, X, Lu, X, Li, F, Yang, G. Effects of Temperature and Carbon-Nitrogen (C/N) Ratio on the Performance of Anaerobic Co-Digestion of Dairy Manure, Chicken Manure and Rice Straw: Focusing on Ammonia Inhibition. PLOS ONE 2014; 9:1-7. DOI: 10.1371/journal.pone.0097265.

[9] Yan, L, Liu, C, Zhang, Y, Liu, S, Zhang, Y. Effects of C/N ratio variation in swine biogas slurry on soil dissolved organic matter: Content and fluorescence characteristics. Ecotoxicology and Environmental Safety 2021; 209:111804. DOI: 10.1016/j.ecoenv.2020.111804.

[10] Yadvika, S, Sreekrishnan, TR, Kohli, S, Rana, V. Enhancement of biogas production from solid substrates using different techniques-a review. Bioresource Technology 2004; 95:1-10. DOI: 10.1016/j.biortech.2004.02.010.

[11] Shahbaz, M, Ammar, M, Korai, RM, Ahmad, N, Ali, A, Khalid, MS, Zou, D, Li, X. Impact of C/N ratios and organic loading rates of paper, cardboard and tissue wastes in batch and CSTR anaerobic digestion with food 
waste on their biogas production and digester stability. SN Applied Sciences 2020; 2: 1436. DOI: 10.1007/s42452-020-03232-w.

[12] Shiratori, Y, Yamakawa, T, Sakamoto, M, Yoshida, H, Kitaoka, T, Tran, QT, Doan, DCT, Dang, MC. Biogas Production from Local Biomass Feedstock in the Mekong Delta and Its Utilization for a Direct Internal Reforming Solid Oxide Fuel Cell. Frontiers in Environmental Science 2017; 5: 25. DOI: 10.3389/fenvs.2017.00025.

[13] Diep, NQ, Sakanishi, K, Nakagoshi, N, Fujimoto, S, Minowa, T. Potential for rice straw ethanol production in the Mekong Delta, Vietnam. Renewable Energy 2015; 74: 456-463. DOI: 10.1016/j.renene.2014.08.051.

[14] Yamakawa, T, Matsubara, H, Shimizu, H, Sakamoto, M, Giang, TT, Shiratori, Y. Lab-scale Methane Fermentation Using Shrimp Pond Sludge and Some Available Biomass on Bên Tre in Vietnam. Journal of the Faculty of Agriculture, Kyushu University 2020; 65: 249-255. DOI: 10.5109/4103700.

[15] Nam, TS, Thao, HV, Ngan, NVC, Kjeld, I. Bio-pretreatment Enhances Biogas Production from Co-digestion of Rice Straw and Pig Manure. International Energy Journal 2021; 21:457-466.

[16] APHA, 1998. Standard Methods for the Examination of Water and Wastewater, 20th ed. American Public Health Association, American Water Works Association and Water Environmental Federation, Washington DC, USA.

[17] Zahan, Z, Othman, MZ, Muster, TH. Anaerobic digestion/co-digestion kinetic potentials of different agroindustrial wastes: A comparative batch study for $\mathrm{C} / \mathrm{N}$ optimisation. Waste management 2018; 71:663-674. DOI: 10.1016/j.wasman.2017.08.014.

[18] Karthikeyan, OP, Visvanathan, C. Effect of $\mathrm{C} / \mathrm{N}$ ratio and ammonia-N accumulation in a pilot-scale thermophilic dry anaerobic digester. Bioresource Technology 2012; 113:294-302. DOI: 10.1016/j.biortech.2012.02.028.

[19] Park, S, Li, Y. Evaluation of methane production and macronutrient degradation in the anaerobic co-digestion of algae biomass residue and lipid waste. Bioresource Technology 2012; 111:42-48. DOI: 10.1016/j.biortech.2012.01.160.

[20] Lin, J, Zuo, J, Gan, L, Li, P, Liu, F, Wang, K, Chen, L, Gan, H. Effects of mixture ratio on anaerobic codigestion with fruit and vegetable waste and food waste of China. Journal of Environmental Sciences 2011. 23: 1403-1408. DOI: 10.1016/S1001-0742(10)60572-4.

[21] Wang, F, Hidaka, T, Tsuno, H, Tsubota, J. Co-digestion of polylactide and kitchen garbage in hyperthermophilic and thermophilic continuous anaerobic process. Bioresource Technology 2012; 112: 6774. DOI: 10.1016/j.biortech.2012.02.064.

[22] Pöschl, M, Ward, S, Owende, P. Evaluation of energy efficiency of various biogas production and utilization pathways. Applied Energy 2010; 87:3305-3321. DOI: 10.1016/j.apenergy.2010.05.011.

[23] Nam, TS, Hong, LND, Thao, HV, Chiem, NH, Viet, LH, Kjeld, I, Ngan, NVC. Enhancing biogas production by anaerobic co-digestion of water hyacinth and pig manure. Journal of Vietnamese Environment 2016; 8: 195-199. DOI: 10.13141/jve.vol8.no3.pp195-199.

[24] Chen, Y, Jiang, X, Xiao, K, Shen, N, Zeng, RJ, Zhou, Y. Enhanced volatile fatty acids (VFAs) production in a thermophilic fermenter with stepwise $\mathrm{pH}$ increase - Investigation on dissolved organic matter transformation and microbial community shift. Water Research 2017; 112: 261-268. DOI: 10.1016/j.watres.2017.01.067.

[25] Ye, J, Dong, L, Yongming, S, Guohui, W, Zhenhong, Y, Feng, Z, Yao, W. Improved biogas production from rice straw by co-digestion with kitchen waste and pig manure. Waste Management 2013; 33: 2653. DOI: 10.1016/j.wasman.2013.05.014.

[26] Mao, C, Zhang, T, Wang, X, Feng, Y, Ren, G, Yang, G. Process performance and methane production optimizing of anaerobic co-digestion of swine manure and corn straw. Scientific Report 2017; 79379. DOI: 10.1038/s41598-017-09977-6.

[27] Srisowmeya, G, Chakravarthy, M, Devi, GN. Critical considerations in two-stage anaerobic digestion of food waste - A review. Renewable and Sustainable Energy Reviews 2020; 119: 109587. DOI: 10.1016/j.rser.2019.109587.

[28] Keramati, M, Beiki, H. The effect of $\mathrm{pH}$ adjustment together with different substrate to inoculum ratios on biogas production from sugar beet wastes in an anaerobic digester. Journal of Energy Management and Technology 2017; 1:1705-1016. DOI: 10.22109/jemt.2017.87623.1016.

[29] Hajji, M, A, Rhachi, M, M, Garoum, M, Laaroussi, N. The effects of pH, temperature and agitation on biogas production under mesophilic regime. In: REDEC 2016 3rd International Conference on Renewable Energies for Developing Countries; 13-15 July 2016: IEEE, pp. 4. DOI: 10.1109/REDEC.2016.7577510.

[30] Vongvichiankul, C, Deebao, J, Khongnakorn, W. Relationship between pH, Oxidation Reduction Potential (ORP) and Biogas Production in Mesophilic Screw Anaerobic Digester. Energy Procedia 2017; 138: 877882. DOI: 10.1016/j.egypro.2017.10.113.

[31] Zhong, B, An, X, Shen, F, An, W, Zhang, Q. Anaerobic Co-digestion of Rice Straw and Pig Manure Pretreated With a Cellulolytic Microflora: Methane Yield Evaluation and Kinetics Analysis. Frontiers in Bioengineering and Biotechnology 2021; 8: 579405. DOI: 10.3389/fbioe.2020.579405. 
[32] Callaghan, FJ, Wase, DAJ, Thayanithy, K, Forster, CF. Continuous co-digestion of cattle slurry with fruit and vegetable wastes and chicken manure. Biomass Bioenergy 2002; 22: 1-77. DOI: 10.1016/S09619534(01)00057-5.

[33] Comino, E, Riggio, VA, Rosso, M. Biogas production by anaerobic co-digestion of cattle slurry and cheese whey. Bioresource Technology 2012; 114: 46-53. DOI: 10.1016/j.biortech.2012.02.090.

[34] Ameen F, Ranjitha, J, Ahsan, N, Shankar, V. Co-digestion of microbial biomass with animal manure in threestage anaerobic digestion. Fuel 2021; 306: 121746. DOI: 10.1016/j.fuel.2021.121746.

[35] Ogata, Y, Ishigaki, T, Nakagawa, M, Yamada, M. Effect of increasing salinity on biogas production in waste landfills with leachate recirculation: A lab-scale model study. Biotechnology Reports 2016; 10: 111-116. DOI: 10.1016/j.btre.2016.04.004

[36] Lee, C, Kim, J, Shin, SG, O’Flaherty, V, Hwang, S. Quantitative and qualitative transitions of methanogen community structure during the batch anaerobic digestion of cheese-processing wastewater. Applied Microbiology and Biotechnology 2010; 87:1963-1973. DOI: 10.1007/s00253-010-2685-1.

[37] Singh, TS, Sankarlal, P. A Review on Advancements in Biogas Technologies. International Journal of Engineering Research and Technology, 2015. TTTCON-2015 Conference Proceedings.

[38] Weiland, P. Biogas production: current state and perspectives. Applied Microbiology and Biotechnology 2010; 85: 849-860. DOI: 10.1007/s00253-009-2246-7.

[39] Rajendran, K, Aslanzadeh, S, Taherzadeh, MJ. Household Biogas Digesters-A Review. Energies 2012; 5: 2911-2942. DOI: 10.3390/en5082911.

[40] Ngan, NVC, Francis, M, MSC, Nam, TS, Thao, HV, Monet, CMD, Hung, DV, Cuong, DM, Hung, NV. Anaerobic Digestion of Rice Straw for Biogas Production in Sustainable Rice Straw Management, M. Gummert, N. V. Hung, P. Chivenge, and B. Douthwaite, Eds. Cham. Springer International Publishing 2020; 65-92. DOI: 10.1007/978-3-030-32373-8_5.

[41] Monteleone, G, Francesco, MD, Galli, S, Marchetti, M, Naticchioni, V. Deep $\mathrm{H}_{2} \mathrm{~S}$ removal from biogas for molten carbonate fuel cell (MCFC) systems. Chemical Engineering Journal 2011; 173:407-414. DOI: 10.1016/j.cej.2011.07.078..

[42] Cristiano, DM, Mohedano, R, Nadaleti, WC, de Castilhos Junior, AB, Lourenço, VA, Gonçalves, DFH, Filho, PB. $\mathrm{H}_{2} \mathrm{~S}$ adsorption on nanostructured iron oxide at room temperature for biogas purification: Application of renewable energy. Renewable Energy 2020; 154:151-160. DOI: 10.1016/j.renene.2020.02.054.

[43] Fortuny, M, Gamisans, X, Deshusses, MA, Lafuente, J, Casas, C, Gabriel, D. Operational aspects of the desulfurization process of energy gases mimics in biotrickling filters. Water Research 2011; 45: 5665-5674. DOI: 10.1016/j.watres.2011.08.029. 